\title{
Toward Excellence in Forestry Education
}

\author{
R.W. Kennedy \\ Dean of Forestry, University of British Columbia
}

\begin{abstract}
Excellence in university forestry education can best be measured by the ability of graduates to analyze, to synthesize, and to discharge and communicate their stewardship of a public resource. Professionals should be devoted to continued learning through the course of their careers. Universities must encourage quality education by recognizing teaching as its paramount task. Curricula should reflect the broader responsibilities of today's manager of the forest estate, and reflect the different but equally important role of the technician. Undergraduate programs may have to be lengthened, while professional and scientific postgraduate programs continue to grow in terms of student numbers. Advanced degree offerings can be enhanced by cooperative arrangements for adjunct professors and sponsored chairs. Practicing foresters can contribute directly to students' education by providing seasonal employment structured to help the students understand and master their chosen profession. Finally, we all must work at enhancing the public understanding of forestry and foresters, so that larger numbers of well-qualified and motivated students are attracted to our profession and its associated colleges and universities.
\end{abstract}

\section{Résumé}

Le meilleur indice de l'excellence dans l'enseignement de la foresterie à l'université est la capacité des diplômés à analyser, à résumer et à transmettre de même qu'à communiquer leur aptitude à gérer une ressource publique. Durant leur carrière, les professionnels devraient s'efforcer d'étendre leurs connaissances. Les universités doivent assurer une éducation de qualité en admettant que leur principale tâche demeure l'enseignement. Les programmes de cours devraient refléter les plus vastes responsabilités du gestionnaire forestier moderne et souligner le rôle distinct mais tout aussi important du technicien. Il est possible qu'on doive prolonger les programmes de premier cycle, même si ceux de deuxième et de troisième cycles destinés à la formation professionnelle et scientifique attirent de plus en plus d'étudiants. Il est possible d'améliorer les études avancées par le biais d'ententes coopératives sur la création de postes de professeur adjoint ou sur le parrainage d'une chaire. D'un autre côté, les forestiers qui pratiquent leur métier peuvent contribuer directement à l'enseignement en proposant aux étudiants des emplois saisonniers qui les aideront à comprendre et à maîtriser la profession qu'ils ont choisie. Enfin, chacun doit s'efforcer de sensibiliser le public davantage à la foresterie et aux forestiers, de telle sorte que la profession, de même que les collèges et les universités qui y sont associés, attireront un grand nombre d'étudiants compétents et motivés.
The public perception of forestry has changed. There is a world-wide trend to participatory democracy and group decision making. Land-use planning, with its environmental and economic overtones, is becoming mandatory. Techniques for information gathering and analysis have improved remarkably, demanding more sophistication in using the results to benefit the society they are to serve. The profession of forestry is under public scrutiny, as are the institutions that have provided the philosophical and technical underpinnings for the profession.

Justice Brandeis of the US Supreme Court once defined a profession as an occupation for which the necessary training is intellectual in character, involving knowledge and learning as distinguished from skill. He also noted that a profession is pursued largely for others and not for oneself. The quality of education that foresters receive will influence the degree to which they can measure up to this professional ideal.

How can university education move us along this path to professional excellence? Most foresters can no longer build their career only by applying scientific expertise to technical problems. They need to relate to people, by listening to and interpreting the interest of various public groups, and by explaining the requirements of their profession and employer to these same public interest groups. Foresters should convey a strong sense of ethics as stewards of renewable resources. Curricula must respond to these changing roles. A university education should launch the graduate on a life-long career of problem identification, critical analysis, and synthesis of a variety of disciplines to provide solutions. Imparting concepts and the ability to exercise reflective judgement presupposes command of a fundamental body of knowledge rather than random facts and techniques. Forestry education demands a mastery of certain facts, which then may be incorporated into a conceptual framework to make decisions affecting the economy, the environment, and the general well-being of society. It is a compelling goal, a complex goal, but a delicately balanced one.

I'm going to present my personal views on this emotional and controversial subject. In doing so, I shall discuss qualities of the universities as transmitters of knowledge, the students as recipients, and the role of the profession and the public in promoting educational excellence. However, this subdivision is artificial, because there is a good deal of interaction between these groupings.

\section{The University}

In striving for excellence, let's first consider the functional role of the university. Teaching, research and service are all important, but the unique role of the university is teaching. The universities provide the basic undergraduate education leading to a development of professional foresters. They are also responsible for educating and training future research scientists and professional educators. There is a chance that the universities could lose sight of this fundamental fact, especially in undergraduate education, in their pursuit of research priorities and the accompanying dollars. Also, there is increasing pressure on faculty, collectively or individually, to take advocacy positions on environmental or forestry 
practice issues. It is important that faculty members participate in the public debates on these issues, within their area of competence and research expertise. However, this activity must be balanced with the priority function of educating students.

To what extent is quality undergraduate education threatened? With the legitimate, increasing emphasis on postbaccalaureate degrees, it has become necessary to provide the specialized laboratory equipment and field costs associated with graduate work. These capital and operating costs have come almost entirely from granting agencies such as the Natural Sciences and Engineering Research Council (NSERC), provincial science councils, FRDA agreements, Forestry Canada and provincial ministries. A small but steadily increasing amount comes directly from industry. These monies not only finance research directly, but provide modest stipends for the graduate students. The university generally must bear the overhead costs because the granting agencies ignore these very real charges. This can compete with the need to support undergraduate programs. Maintaining research financing can be nearly a full-time occupation of faculty, with successive rounds of preparation of proposals to granting agencies, peer review, and consequent periodic reporting. The trend today is toward partnership research, in which industry and government share the financial decision making. This generally assures that the sponsored research is more relevant to real need, but it further complicates the process of obtaining financial support.

The personal reward system for the ambitious professor has been through granting of tenure and promotion. Research productivity bears heavily on these decisions, and can be semiquantified by the frequency and length of publications in peerreviewed journals, and also by the nature and amount of research grants received. Undergraduate teaching is more difficult to evaluate, and thus tends to be weighted less heavily than research. Mediocrity in teaching may be tolerated as long as research productivity is substantial, but the reverse is not usually true. Concentration on research and its associated postgraduate instruction can relegate the undergraduate teaching and community service functions to lower priorities.

The role of independent advocate or spokesman is often considered by faculty members as a less productive way of spending time. However, dodging this responsibility is relatively rare, as there is a certain immediacy to many requests, and an opportunity to influence a large segment of public opinion. Pressure is growing for more outspoken public involvement, but to be properly done, it subtracts from other functions, including teaching.

Universities have taken measures to counteract erosion of teaching excellence. Many have created Master Teacher Awards to recognize outstanding individuals and their contributions. Student evaluations of courses and professors are commonplace, and aid both the individual teacher and promotion decisions. In cooperation with faculty associations, short seminars are being offered to address methodology of teaching, but a more rigorous and regular approach to better teaching methods could benefit faculty and students alike.

High quality teaching also involves updating laboratories both in equipment and subject content, and setting limits on instruction by well-intentioned but sometimes less informed graduate students. Most importantly, it requires thoughtful assignments, where students must think critically, reflect objectively, and write clearly. There should be more time for the students to react creatively with their professors in and out of the classroom and laboratory.

The breadth and depth expected of a professional forester has become increasingly difficult to obtain in four years of undergraduate study. Foresters should be aware of the sociological as well as the environmental impact of resource decisions; they should understand land-use planning and have skills to resolve conflicts over the management of all the resources of the forests; they should understand organizational behaviour and the psychology of leadership; they should understand principles of business management and law as they apply to natural resource management. Clearly attainment of this litany of attributes must seriously compromise some of the technological and scientific training traditional to the forester. But if the profession and its educational underpinnings don't change, other disciplines will assume the more important managerial and decision-making roles, and leave the professional forester in an ambiguous position, hardly distinguishable from the forestry technician. It's time for a new dialogue with the colleges and institutes offering technical post secondary forestry courses, with the aim of establishing clear, but separate mandates for both. The end result may be less rather than more transfer credits from technical to degree programs, but the resultant university graduate could be more valuable to today's complex society.

How can we enhance and improve the educational experience of a forester to make him more responsive to changing social, economic and environmental conditions? The broader responsibilities and expectations should demand a longer and continuing process of education. I question whether the traditional four-year program, with only one-half year of formal instruction per calendar year, is any longer adequate. Sweden and Finland require about five years of significantly longer terms, in which to educate professional foresters. If it is important to provide the appropriate courses in the humanities, to develop the capacity to reflect and think creatively and to communicate clearly through more written and oral assignments, then the student needs a longer period of resident instruction at the university. In 1983, the forestry program at UBC moved from a five-year to a four-year program. In hindsight, this change may have been unwise, and in fact goes against the trend of many degree programs in other professions throughout the country.

One of the arguments against a longer undergraduate degree program is that specialization can be employed to produce the appropriate depth of learning. Although specialized programs in certain fields such as wood products, forest engineering, or recreation and wildland management can serve a purpose, I'm not at all sure that significant specialization within the expanding field of forest resources management can work, because breadth has to be sacrificed to achieve depth. The strength of the professional forest resources manager perhaps should be that of a generalist with enough knowledge to be able to ask the right questions of the specialists, and to apply their disciplinary advice.

An alternative to a longer undergraduate program is the professional Master's degree. This could give the opportunity to specialize in a narrower operational phase of forestry, be it silvicultural, wildlife management, or timber management. However, such programs are accessible only to the better academic achievers who are acceptable to the graduate school of a university. There is a middle ground involving a diploma 
offering of fixed courses with no research component that might be implemented. Whatever the method of delivery of a program it seems inevitable that more time should be spent in formal instruction at the university.

Post-graduate courses and student numbers should continue to grow. More attention should be given to steering good Canadian students into graduate work to provide the disciplinary specialists, the researchers, and professors of tomorrow. Graduate programs have increased over recent years, contrary to undergraduate enrollments, but about half of the students across the country are non-Canadian. This necessarily limits their long-term commitment to a working career in Canada. More effort should be directed at recruiting graduate students into forestry faculties from other disciplines at Canadian universities. Often a biochemist, microbiologist, phyiologist, economist, or engineer can make an outstanding contribution to research by applying his expertise to forestry or forest products problems.

Graduate programs in several universities are now at a level of development and student numbers to justify an increasing number of formal courses of instruction to enhance the research aspects of the degree. Collaboration with other faculties is evident, and a system of adjunct professors from a variety of government and industrial laboratories is further evidence of a wide spectrum of post-graduate undertakings. A relatively recent innovation for adding to capabilities in post-graduate research and education is that of the NSERC/Industrial Research Chair. This has enabled faculties to strengthen their graduate programs by adding senior professors in partnership arrangements between NSERC and industrial sponsors. In some cases there have been limited contributions from provincial ministries. There is now some suggestion that Forestry Canada might also participate in a similar program. These chairs thus far have been a useful means of drawing forestry faculties and their industrial sponsors closer together. However, the chairs have a finite life of five years, so to provide tenure and permanency they must be linked to anticipated retirements or vacancies. This bridging may jeopardize downstream flexibility of faculties, since tenure commitments for these chairs must be made against future vacancies. This problem could be alleviated by applying a portion of the annual instalments received to a sinking fund to permanently endow the chair after the initial five-year period has expired.

\section{The Profession}

The baccalaureate degree is only a ticket to life-long learning and intellectual growth. The professional forestry associations in the various provinces should take the leadership to ensure that their members are continually updated on forestry issues, scientific developments, techniques and conflict resolution. They may work together with the universities and experts in industry and government to provide the continuing education courses necessary to professional growth and development. Employers should encourage their personnel to capitalize on opportunities for continuing professional education, to foster better decision-making among more well informed staff. The universities should be prepared to do their part, and recognize continuing professional education as a vital part of their mandate.

In B.C., a series of five professional continuing education modules has been initiated under the aegis of the Silvicultural
Institute of B.C. (SIBC). Qualifications to enrol in this program include R.P.F. status and five years of field experience. Courses are delivered through university, government, and industry specialists, culminating in preparation of silvicultural prescription in a field setting. The University staff has assisted in course organization and implementation, and office space for the executive director has been provided with the Faculty of Forestry. Direct funding has been through the FRDA program. Of course, silviculture is only one of several subject areas requiring regular updating to keep practitioners current. Other universities offer regularly scheduled short courses on a variety of subjects.

A program for accreditation of forest resources management and harvesting curricula has been instituted through the joint efforts of the Association of University Forestry Schools in Canada (AUFSC) and the Canadian Federation of Professional Foresters Associations (CFPFA). A Canadian Forestry Accreditation Board has been established to evaluate forestry faculties against standards of curriculum, staffing, and facilities. This periodic form of outside assessmment can benefit the educational process by ensuring that well-qualified professors deliver updated course material using the best possible equipment and techniques. Accreditation reviews may also have a down side if criteria for curricula review are so rigid that they inhibit the easy introduction of new courses and subjects in place of others deemed essential in the past. The inherent danger is that advisory and review committees may be either too resistant or too eager to change. Simple awareness of this danger should go a long way toward ensuring that accreditation reviews are positive, both in process and outcome.

Industry and government, as summer employers, have an important role to play in contributing to excellence in forestry education. Although some formal, cooperative employment programs are in place, and an apprenticeship work year may be arranged in some universities, most summer employment has been rather casual and informal in regard to learning on the job. Some individual supervisors have been diligent in assuring the student a variety of field and learning experiences, while others have not. A more formal approach to summer employment as an apprenticeship, incorporating increased responsibilities and challenges consistent with the level of education and experience of the student, would be welcomed. Research linkages between forestry faculties and the public and private sectors have increased dramatically of late, owing to a variety of partnership programs. It is time to devote more attention to truly cooperative educational work programs with these same organizations.

\section{The Students}

Reform in teaching and curricula is only one aspect of striving for excellence. The number and quality of incoming students are also critical. Whether or not we like it, and whether or not it is fair, public perception of the forester and his profession is not high. We are seen by some as partly responsible for fanciful or real deficiencies in forest management, but we need to be regarded as caring professionals acting as stewards of the forest resources. If we can improve our image, we can attract students to the challenging times ahead. A better informed public is a prerequisite to recruiting more highly qualified entrants to university forestry programs. Many companies are responding to this challenge by 
inviting the public to visit their operations and by discussing their management and harvesting plans with concerned citizens groups. The universities also have a part to play in interpreting forestry to the general public. For example, at UBC this fall we are instituting a general continuing education course on important forestry issues, and have structured it to include formal responses from government, industry and environmental activists.

Most universities have also produced videos to emphasize the challenge and complexity of forestry programs. Although these videos can serve a general audience, they are intended specifically to attract secondary school students. Efforts by governments, industry and universities are necessary to overcome the perceptual bias against forestry in general, to meet the demands for numbers and quality of graduates. Ideally, a pre-admission interview of promising candidates for entrance should be conducted, and prior practical forestry experience should be weighed heavily. But until we have many more applicants than at present, we must continue to accept all who qualify, and suffer a high drop-out rate in first year, particularly among the less mature, immediate entrant from secondary school. By comparison, Finland and Sweden have 8 to 10 times more applicants than initial entrants. The cultural conditioning in these countries, where responsible and intensive forest management has been prac- tised for many decades, certainly contributes to this evidently competitive status as a forester.

\section{Summary}

Excellence in university forestry education can best be measured by the ability of graduates to analyze, to synthesize, and to discharge and communicate their stewardship of a public resource. Professionals should be devoted to continued learning through the course of their careers. Universities must encourage quality education by recognizing teaching as its paramount task. Curricula should reflect the broader responsibilities of today's manager of the forest estate, and reflect the different but equally important role of the technician. Undergraduate programs may have to be lengthened, while professional and scientific post-graduate programs continue to grow in terms of student numbers. Advanced degree offerings can be enhanced by cooperative arrangements for adjunct professors and sponsored chairs. Practicing foresters can contribute directly to students' education by providing seasonal employment structured to help the students understand and master their chosen profession. Finally, we all must work at enhancing the public understanding of forestry and foresters, so that larger numbers of well-qualified and motivated students are attracted to our profession and its associated colleges and universities.

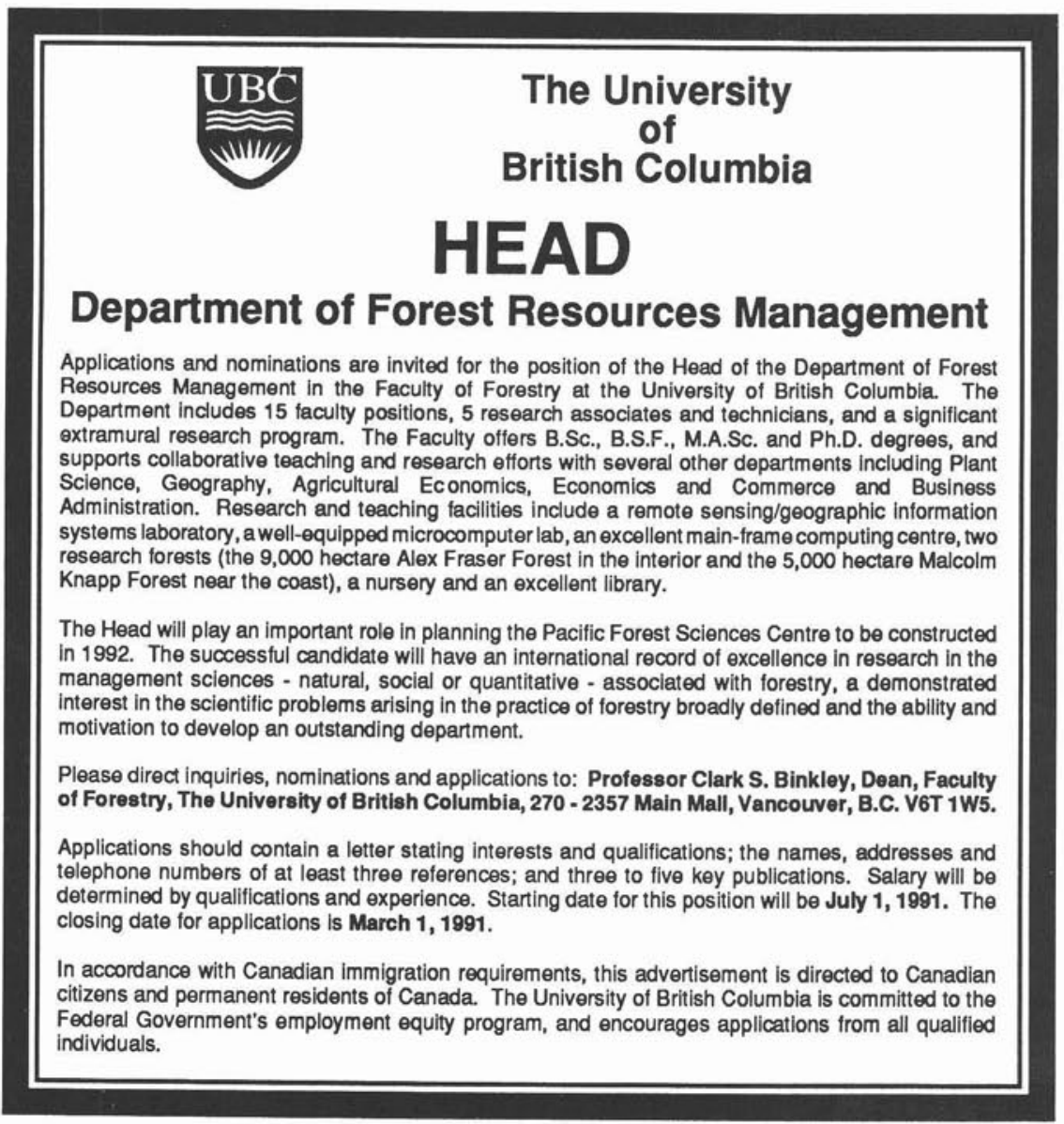

